\title{
Die Typhusepidemie in Detmold und die Trinkwassertheorie.
}

\author{
Eine kritische Studie
}

ron

\section{Dr. Auerbach,}

Arzt in Detmold

Mit sieben Textabbildungen.

Sondersbdruck ans dem Journal für Gasbeleachtung and Wasserversorgang.



München und Berlin.

Druck und Verlag von R. Oldenbourg.

190 . 
